\title{
ENHANCING DESCRIPTIVE PARAGRAPH WRITING OF SECONDARY STUDENTS THROUGH SHARED WRITING
}

\author{
Mutiara Ayu ${ }^{1}$, Zuraida ${ }^{2}$ \\ Universitas Teknokrat Indonesial \\ Universitas Sriwijaya ${ }^{2}$
}

mutiara.ayu@teknokrat.ac.id, zuraida.unsri@gmail.com²

\begin{abstract}
The objective of the study is to find out whether or not there was a significant difference in descriptive paragraph writing enhancement of secondary students who were taught through shared writing and those who were not. This study was conducted by using an experimental method. The sample of the study was 35 eighth grade students taken by using convenience sampling technique, 18 students belonged to experimental group and 17 students belonged to control group. The data were collected through pretest and posttest. In order to maintain validity, content validity was applied. Then, two raters were used to maintain reliability of the result. The experimental group was taught for twelve meetings by using Shared Writing. The result showed the students in the experimental getting the mean 14.67 with standard deviation 2.058 and control group getting the mean 12.00 with standard deviation 1.414 got a significant improvement in the posttest. There was a better significant improvement in descriptive paragraph writing in the experimental group who are taught by using Shared Writing if compared to the students in the control group.
\end{abstract}

Keywords: Shared writing, descriptive paragraph writing

\begin{abstract}
To cite this article:
Ayu, M. \& Zuraida. (2020). Ehnanching Descriptive Paragraph Writing of Secondary Students through Shared Writing. Jurnal of Research on Language Education, 1(1), 13-18.
\end{abstract}

\section{INTRODUCTION}

Writing is one of the important language skills that has got to be taught in schools. Writing is the language skill which will neither be neglected nor omitted from communicative pedagogy and learning. If teaching of English writing doesn't involve the abilities that has to be taught, it means the teacher doesn't fulfill what the curriculum requires. Doing writing is doing variety of activities that relate to every other like the method of setting objectives, generating ideas, making a draft, and so on. These activities must be managed well to attain the goal of writing itself. Hedge (2000) states that writing is that the results of employing strategies to manage the composing process, which is one among gradually developing a text. It involves variety of activities, such as setting goals, generating ideas, making a draft, reading and reviewing it, then revising and editing. The students must learn the way to compose sentences, build paragraph and express idea within standards of written English.

Learning to write down could be a challenging, because it is multi skilled process. Students must find out how to spot, analyze, and develop ideas. Therefore, the teacher needs to include writing collectively of the abilities that has got to be taught within the teaching and learning activities. Writing can give the chance to the students who don't want to talk directly. By writing, they will express their feeling. This statement is supported by Chin (1990). He states that through writing someone brings information and expresses his/her thoughts, ideas and feeling to others. As Leo (2007) states that writing is as a process of expressing ideas or thoughts in words should be done at our leisure. To start writing, the students must ask themselves whether or not they have enough time to write down and whether or not they enjoy it. How the students can write if they're not provided enough time to put in writing in class.

For EFL students, the more they think, the more they trap unsure to start writing. There are some reasons why students hand over in completing their assignment. In line with Carolan and Kyppö (2015), the 
students take an extended time to master the writing skill thanks to several reasons. First reason is words in thousand; the vocabulary mastery of students is different among one another, because their capabilities are different. Younger students have difficulties to rearrange the words to form a sentence thanks to their vocabulary limitation and inability to precise their idea into communication. Second, they are doing not know the way to correct mistakes. The last is main purpose of writing activity is to catch grammar, spelling and punctuations errors.

Despite the importance of writing ability, many students complain that they are doing not have a decent competence in writing. Hedge (2005) indicates that writing has cared-for a far more neglected a part of the language program both in first and foreign or second pedagogy for a few years. Many students don't realize two things. First, as a matter of fact, writing is complicated for nearly everyone. In classroom activities, students believe that developing writing skill is more complicated than developing other language skills so most of the student dislike writing.

To solve this problem, it is believed that teaching strategy used by teachers can help students in writing English in the classroom. One of the effective strategies is shared writing. Shared writing involves the teacher and a gaggle of scholars - often the entire class - in planning and constructing a text together (Gibson, 2011). The teacher models, talks through the method of constructing a text or a part of one and offers explicit instruction in a way to use writing strategies during the shared writing process. the scholars contribute their ideas and expertise to the method of constructing the text. Through shared writing, students can participate in constructing a more complex text than they might be ready to pen their own. Every student employs certain strategies and designs to support the attainment of learning objectives (Ayu, 2018; Mandasari and Oktaviani, 2018; Aminatun and Oktaviani, 2019).

In shared writing, the teacher and students compose collaboratively, the teacher acting as expert and she or he demonstrates, guides, and negotiates the creation of meaningful text. Modeling will be used as an instructional strategy to indicate students, step by step, the look, shaping, and structuring of a text for a particular purpose. Wang (2016) states in their article that carefully planned questions can help the scholars to give some thought to how a selected text may well be organized. The teacher may prompt by showing them similar familiar material or by reviewing with them the features of a selected form of text. This approach enables the teacher to show students to new, rich language, adding to the range of vocabulary and language structures that they'll use in their personal writing. Shared writing reinforces positive attitudes towards writing by making it an agreeable and inventive activity. the aim of shared writing is to model the thought process involved in writing and permit students to have interaction in and target the method.

Bjorn (2009) explains in his article entitled "Using Shared Writing to show Children" that the teacher, acting as scribe, frees students from that aspect of the writing process in order that they'll focus exclusively on the thinking involved in writing. Shared writing is additionally a robust method for direct teaching of key skills and ideas needed within the writing process. Moreover, shared writing could be a step within the process of moving students toward independent writing. consistent with Ware and Warschauer (2006), shared writing is another level within the scaffold that offers students support as they learn the mechanics, conventions, and processes of writing. The strategy allows students to realize competence and confidence in their writing skills while it allows the teacher to demonstrate the usually internal thinking process that takes place because the writers write. The text can serve a particular purpose governed by what's happening currently within the classroom or the teacher and students can brainstorm and negotiate these decisions together. Therefore, the writer's aim of this research is to find out significant difference in descriptive paragraph writing enhancement of secondary students who were taught through shared writing and those who were not.

\section{RESEARCH METOD}

The method which was used by the writer in conducting this study is experimental method. The writer used one of quasi-experimental designs: pre-test post-test non equivalent group design. This study was done in SMP Negeri 41 Palembang. The writer used convenience sampling technique. The treatment was done in the VIII.6 that consisted of 35 students, they were divided into two groups randomly, that is, the odd numbers belonged to experimental group and the even numbers belonged to control group.

The writer gave the tests twice (pretest and posttest) by using the same instruction in order to know whether the students' descriptive writing achievements increase or not. The first test or pretest was administrated before the writer started the experimental teaching and the second test or posttest was administrated at the end of the experiment. In the pretest and posttest, the tests were assigned to write a descriptive paragraph of 75-100 words in length 45 minutes. 


\section{FINDINGS AND DISCUSSION}

The result of both pretest and posttest in the experimental and control groups were analyzed by using ttest. The analysis was done by using SPSS program.

\section{THE RESULT OF NORMALITY DATA OF PRETEST AND POSTTEST IN EXPERIMENTAL GROUP}

Before doing the statistical analyses, first of all, the writer measured the normality of the data. In the analyzing the normality data, kolmogrov-smirnov test was used. The kolmogrov-smirnov test of the pretest of the experimental group showed Asymp. Sig. (2-tailed) was 0.226 . Since 0.226 is higher than 0.05 , so it can be concluded that the data obtained was considered normal. The kolmogrov-smirnov of the posttest of the experimental group showed that Asymp. Sig. (2-tailed) was 0.563. Since .563 is higher than 0.05 , so, it can be concluded that the data obtained was considered normal. The complete result of the kolmogrov-smirnov test can be seen in table below.

Table 1. Test of Normality Pretest-Posttest of Experimental Group One-Sample Kolmogorov-Smirnov Test

\begin{tabular}{llrr} 
& & \multicolumn{1}{c}{$\begin{array}{c}\text { Pretest } \\
\text { Experimental }\end{array}$} & $\begin{array}{c}\text { Posttest } \\
\text { Experimental }\end{array}$ \\
\cline { 3 - 3 } N & & 18 & 18 \\
Normal Parameters ${ }^{\mathrm{a}, \mathrm{b}}$ & Mean & 12.39 & 14.67 \\
& Std. Deviation & 1.944 & 2.058 \\
Most Extreme Differences & Absolute & .246 & .186 \\
& Positive & .246 & .092 \\
& Negative & -.126 & -.186 \\
Kolmogorov-Smirnov Z & & 1.043 & .789 \\
Asymp. Sig. (2-tailed) & & .226 & .563 \\
\hline
\end{tabular}

a. Test distribution is Normal.

b. Calculated from data.

\section{THE RESULT OF NORMALITY DATA OF PRETEST AND POSTTEST IN CONTROL GROUP}

Before doing the statistical analyses, first of all, the writer measured the normality of the data. In the analyzing the normality data, kolmogrov-smirnov test was used. The kolmogrov-smirnov test of the pretest of the control group showed Asymp. Sig. (2-tailed) was 0.779. Since 0.779 is higher than 0.05, so it can be concluded that the data obtained was considered normal. The kolmogrov-smirnov of the posttest of the control group showed that Asymp. Sig. (2-tailed) was 0.467. Since 0.467is higher than 0.05, so it can be concluded that the data obtained was considered normal. The complete result of the kolmogrov-smirnov test can be seen in table below.

Table 2. Test of Normality Pretest-Posttest of Control Group One-Sample Kolmogorov-Smirnov Test

\begin{tabular}{|c|c|c|c|}
\hline & & Pretest Control & Posttest Control \\
\hline $\mathrm{N}$ & & 17 & 17 \\
\hline \multirow{2}{*}{ Normal Parameters ${ }^{\mathrm{a}, \mathrm{b}}$} & Mean & 11.06 & 12.00 \\
\hline & Std. Deviation & 1.853 & 1.414 \\
\hline Most Extreme & Absolute & .160 & .206 \\
\hline Differences & Positive & .160 & .206 \\
\hline & Negative & -.134 & -.147 \\
\hline Kolmogorov-Smirnov Z & & .659 & .849 \\
\hline Asymp. Sig. (2-tailed) & & .779 & .467 \\
\hline
\end{tabular}

a. Test distribution is Normal.

b. Calculated from data.

\section{STATISTICAL ANALYSIS ON THE RESULT OF PRETEST AND POSTTEST IN EXPERIMENTAL GROUP}

The mean of pretest in experimental group was 12.39, the standard deviation was 1.944 , and the standard error mean was 0.458 ; the mean of posttest in experimental group was 14.67 , the standard deviation was 2.058 , and the standard error mean was 0.485 . Table 3 presents the statistics of experimental group. 
Journal of Research on Language Education (JORLE), Vol: 1, No: 1, 13-18

Table 3. Paired Samples Statistics of the Experimental

\begin{tabular}{llcccc}
\hline & Mean & $\mathbf{N}$ & Std. Deviation & $\begin{array}{c}\text { Std. Error } \\
\text { Mean }\end{array}$ \\
\hline Pair 1 & $\begin{array}{l}\text { Posttest Scores in Experimental } \\
\text { Group }\end{array}$ & 14.67 & 18 & 2.058 & .485 \\
& $\begin{array}{l}\text { Pretest Scores in Experimental } \\
\text { Group }\end{array}$ & 12.39 & 18 & 1.944 & .458 \\
\hline
\end{tabular}

Table 4 shows the result of the paired sample t-test of the experimental group.

Table 4. The Paired Sample Test of the Experimental Group

\begin{tabular}{llc}
\hline & & Pair 1 \\
\cline { 3 - 3 } & & \\
\cline { 3 - 3 } & & $\begin{array}{c}\text { Posttest Scores and Pretest } \\
\text { Scores }\end{array}$ \\
\hline Paired differences mean & & 2.278 \\
$\quad$ Std. Deviation & & 1.841 \\
Std Error Mean & & 0.434 \\
95\% Confidence Interval & Lower & 1.362 \\
$\quad$ Of the Difference & Upper & 3.193 \\
$\mathrm{t}$ & & 5.250 \\
df & & 17 \\
Sig. (2-tailed) & .000 \\
\hline
\end{tabular}

It means that there was significant difference between pretest and posttest scores in experimental group. On the other hand, the improvement happened in experimental group.

STATISTICAL ANALYSIS ON THE RESULT OF PRETEST AND POSTTEST IN CONTROL GROUP

Based on paired sample statistics (Table 3), the mean of pretest in control group was 11.06, the standard deviation was 1.853 , and the standard error mean was 0.449 ; the mean of posttest in control group was 12.00 , the standard deviation was 1.414 , and the standard error mean was 0.343 . Table 5 presents the statistics of control group.

Table 5. Paired Samples Statistics of the Control

\begin{tabular}{cccccc}
\hline & Mean & N & Std. Deviation & $\begin{array}{c}\text { Std. Error } \\
\text { Mean }\end{array}$ \\
\hline Pair 1 & Posttest Scores in Control & 12.00 & 17 & 1.414 & .343 \\
& Pretest Scores in Control & 11.06 & 17 & 1.853 & .449 \\
\hline
\end{tabular}

Table 6 shows the result of the paired sample t-test of the experimental group.

\begin{tabular}{lcc}
\multicolumn{2}{c}{ Table 6. The Paired Sample Test of the Control Group } \\
\hline & & Pair 1 \\
\cline { 2 - 2 } & & $\begin{array}{c}\text { Posttest Scores and Pretest } \\
\text { Scores }\end{array}$ \\
& & 0.941 \\
Paired differences mean & 1.345 \\
Std. Deviation & & 0.326 \\
Std Error Mean & Lower & 0.250 \\
95\% Confidence Interval & 1.633 \\
Of the Difference & Upper & 2.885 \\
t & & 16 \\
df & & .001 \\
Sig. (2-tailed) & \\
\hline
\end{tabular}

Paired sample difference in mean between pretest and posttest in control group was 0.941with standard deviation 1.345, standard error was 0.326 and t-obtained was 2.885. Since the Sig. (2-tailed) pair 1 was 0.001 that was less than the value of probability 0.05 . It means that there was significant difference between pretest and posttest scores in control group. It means the improvement also happened in control group. However, the data 
showed that the students in experimental group got more improvement than that of control group. The average scores of posttest in experimental group was higher with score 18 than the posttest in control group with score 16.

\section{INTERPRETATIONS}

Based on the findings, the writer finally comes to the interpretations. The students in the experimental group showed improvement in their descriptive paragraph writing. The significant difference between the mean score of pretest and posttest was assumed to have been influenced by shared writing. The mean of the students' score in the experimental group was 14.67 with standard deviation 2.058 and the mean of students' score in the control group was 12.00 with standard deviation 1.414. The students in the experimental group with the mean 14.67 made a better improvement in descriptive paragraph writing compared to those of the students in control group with the mean 12.00 after the treatment given. It might be because the students in the control group were lack of practice in writing.

The writer assumed that shared writing allows the students in the experimental group to participate in the writing process by contributing ideas and knowledge without the pressure of having to write their own at the first few meetings. The writer talked through the process of constructing a paragraph and gave instruction in how to use writing strategies during the shared writing process. The students contributed their ideas to construct the paragraph. Through shared writing, students could take part in constructing the paragraph.

Moreover, shared writing involves the teacher and students collaboratively composing a paragraph. Shared writing is an effective way to improve students' writing skill. Fischer (2002) states that by using shared writing, the students can see the text growing slowly and carefully as the teacher scribes, and they can be encouraged, in this supportive environment, to contribute ideas. This is very valuable for students who are experiencing difficulties in writing, including those who lack of confidence or motivation. The teacher also provided materials related to the topics discussed through online. Most of the students perceived the various elearning materials provided to be rather helpful because teaching materials or materials were easily accessed online and were relevant for use (Ayu, 2020).

The writer could interpret the students in experimental group applied this strategy. The writer introduced the students how to apply shared writing in writing descriptive paragraph in the second meeting. In this meeting, the writer found that the students were not accustomed to using this strategy because they usually write individually than corporately or write together. However, the students were gradually accustomed to apply this strategy since the fourth meeting. During the experiment, the writer and students negotiated and decided topics in the previous meeting.

In the next meeting, the writer applied the process of peer writing and editing in the class. The students did peer editing with their friend sitting next to them while the writer was monitoring them. Once the students received comments and feedbacks from their peers, they were required to revise and edit their work. At the end of the revision session, they were given a week to continue commenting on their peers' drafts. It helped each other to eliminate simple grammar mistakes, spelling and typo errors, as well as correct format, organization of ideas within each sentence (Wahyudin, 2018).

According to Murau (1993), with regard to peer review, the students asked peers to check their papers, and even then, most felt anxious or embarrassed, but found it helpful and necessary to get someone else's feedback. It helped them to get along with others and gave them an opportunity to get to know their classmates better. This interactive activity can motivate and engage students with learning activities and create their interest in learning English in classrooms. Promoting interactive activities such as forcing students' engagement in pairs, group discussions and presentations can be alternative ways to aid students to learn English in a meaningful way and make them communicate effectively in English during the teaching and learning process (Ayu, 2018).

The result showed clearly that shared writing enabled some students create richer body of content. They developed the topic from different points of view, thus strengthening the quality of their descriptive paragraph. Shared writing also helped the students organize and edit papers well through peer editing. It is also proved by Mulligan \& Garofalo (2011). They state collaborative writing assignments and peer editing, as done in pairs or small group, can have numerous effective benefits for the learners. The process of peer writing and editing can be effective in raising students' awareness of important organizational and syntactical elements that they otherwise might not notice on their own.

Finally, it can be interpreted that shared writing strategy contributed to the students' improvement in descriptive paragraph writing. It can be seen from the students' results in the experimental group. The students in the experimental group got a better achievement in descriptive paragraph writing compared to the students in the control group 


\section{CONCLUSION}

Based on the result of the findings and interpretations, it can be concluded that the teaching of writing by shared writing improved the students' descriptive paragraph writing. The experimental group students were able to obtain higher scores than the scores of control group students. Although these two groups of students made in progress, but the progress of control group in writing achievement was not as high as the progress of experimental group students was. In other words, there was a significant difference between the students who were taught by Shared Writing and the students who were not. Therefore, the writer assumed that shared writing has improved the scores in students' descriptive paragraph writing of the experimental group.

\section{REFERENCES}

Aminatun, D. \& Oktaviani, L. (2019). Memrise: Promoting Students' Autonomous Learning Skill through Language Learning Application. Metathesis: Journal of English Language Literature and Teaching, 3(2), $214-223$.

Ayu, M. (2018). Interactive activities for effective learning in the overcrowded classroom. Linguists, 4(2), 1-6.

Ayu, M. (2020). Online learning: Leading e-learning at higher education. The Journal of English Literacy and Education, $7(1), 47-54$.

Bjorn. K. (2009). Using shared writing to teach children (online). Retrieved from http://www.idealcurriculum.com/aboutus.html.

Carolan, F., \& Kyppö, A. (2015). Teaching process writing in an online environment. Voices of pedagogical DevelopmentExpanding, enhancing and exploring higher education language learning, 13.

Chin, B. (1990). On your own: Writing process. Eaglewood Cliffs, NJ: Prentice-Hall, Inc.

Fischer. (2002). Shared thinking: Metacognitive modelling in the literacy hour. Literacy, 36(2):63-67.

Gibson, S.A. (2011). Strategy guide series teaching writing (online). Retrieved from http://www.readwritethink.org/professional-development/strategy-guides/shared-writing-30686.html

Hedge, T. (2005). Writing. New York, NY: Oxford University Press.

Leo, S. (2007). English for academic purpose: Essay writing. Yogyakarta, INA: Andi Offset.

Mandasari, B., \& Oktaviani, L. (2018). English language learning strategies: an exploratory study of management and engineering students. Premise: Journal of English Education and Applied Linguistics, 7(2), 61-78.

Mulligan, C. \& Garofalo, R. (2011). A collaborative writing approach: Methodology and student assessment. The Language Teacher, 35(3),5- 10.

Murau, A.M. (1993). Shared writing: Students' perceptions and attitudes of peer review. WPEL Journal, 9(2), $71-79$.

Storch, N. (2005). Shared writing: Product, process, and students' reflection. Journal of Second Language Writing, 3(14), 153-173.

Wahyudin, A.Y. (2018). The impact of online peer feedback on efl students writing at tertiary level. Bahtera: Jurnal Pendidikan Bahasa Dan Sastra, 17(1), 1-10.

Wang, W. (2016). Peer feedback in Chinese college English writing Class: using action research to promote students' English writing. Journal of Language Teaching and Research. 7 (5), 958-966.

Ware, P. D., \& Warschauer, M. (2006). Electronic feedback and second language writing. Feedback in second language writing: Contexts and issues, 105-122.

Zhu, W. (2001). Interaction and feedback in mixed peer response group. Journal of Second Language Writing, 4(10), 251276.

\section{BIOGRAPHIES OF AUTHORS}

Mutiara Ayu is an English Education Lecturer in Universitas Teknokrat Indonesia. She actively participates as a presenter at national and international conferences and publishes her studies in journals. Her research interest is English teaching and learning, teaching strategies, textbook evaluation, and TEYL.

Zuraida is an English Education Lecturer in Universitas Sriwijaya. She actively participates as a presenter at national and international conferences and publishes her studies in journals. Her research interest is writing skill, listening skill, and teaching strategies. 